\title{
How canopy structural and morphological characteristics, and forage chemical composition affect a pasture-based dairy system?
}

\section{Como as características estruturais e morfológicas do dossel, e a composição química da forragem afetam um sistema de produção de leite em pastagem?}

\begin{abstract}
Cláudia de Paula Rezende1; José Marques Pereira²; Albertí Ferreira Magalhães; Igor Machado Ferreira ${ }^{4}$; Bruno Grossi Costa Homem*; Daniel Rume Casagrande ${ }^{6}$
\end{abstract}

\section{Highlights}

Structural and morphological characteristics are more correlated with Mombasa grass.

Forages of erect growth have greater stem proportion in the forage mass.

Canopy structure characteristics are the main factors determining milk yield per area.

\section{Abstract}

Pasture-based systems are prevalent among small-scale family farms. Many farmers consider that the nutritional value of the plant is more relevant than the canopy structure. This study aimed to analyze the various factors related to plant structure and chemical composition that most influence milk yield per hectare under rotational stocking. The experiment was performed at the Animal Husbandry Experimental Station of the Extreme South of Bahia. Three rotational stocking systems with three forage species [Cynodon dactylon (L.) Pers. cv. Tifton 85, Urochloa brizantha (Hochst. ex A. Rich.) Stapf. cv. Xaraés, and Megathyrsus maximus Jacq. cv. Mombasa] were evaluated. Nine crossbred Holstein x Gyr cows were allocated to a balanced $3 \times 3$ Latin square design. The cows were rotated in three pastures every 14 days. The experimental period consisted of seven evaluation cycles of 42 days each. Cluster analysis, principal

1 PhD. in Animal Science, Estação Experimental de Pecuária do Extremo Sul da Bahia, CEPLAC-ESSUL, Itabela, BA, Brazil. E-mail: claudiaprezende@hotmail.com

2 Prof. PhD., Department of Agronomy, Universidade Estadual de Santa Cruz, UESC, Ilhéus, BA, CEPLAC/CEPEC, Itabuna, BA, Brazil. E-mail: josem.pereira@agricultura.gov.br

3 PhD. in Animal Science, CEPLAC/CEPEC, Itabuna, BA, Brazil. E-mail: alberti.magalhaes@agricultura.gov.br

${ }^{4}$ Master in Animal Science, Universidade Estadual Paulista Júlio de Mesquita Filho, UNESP, Câmpus Jaboticabal, Jaboticabal, SP, Brazil. E-mail: igorzootecnia@yahoo.com.br

${ }^{5}$ PhD. in Animal Science, Empresa Brasileira de Pesquisa Agropecuária, EMBRAPA Agrobiologia, Seropédica, RJ, Brazil. E-mail: grossizoo@hotmail.com

${ }^{6}$ Prof. PhD., Department of Animal Science, Universidade Federal de Lavras, UFLA, Lavras, MG, Brazil. E-mail: danielcasagrande@ufla.br

* Author for correspondence

Received: Sept. 22, 2020 - Approved: June 23, 2021 
component analysis (PCA), and multivariate linear regression were the statistical techniques used to evaluate plant structure and morphological characteristics, and animal performance. Xaraés palisadegrass and Mombasa guinea grass were similar for all evaluated characteristics $(P>0.05)$, whereas Tifton 85 was different from them in terms of structural, morphological, and chemical composition characteristics $(P<$ 0.05). In the PCA, 59.1\% of the total variance was explained by components 1 and 2 for the structural and morphological characteristics, and forage chemical composition. Forage structural and morphological variables showed better results in the multivariate linear regression analysis for milk yield per hectare. Structural and morphological characteristics were more correlated with Mombasa guinea grass than Xaraés palisadegrass and Tifton 85. The structural and morphological characteristics of forages were the main factors determining milk yield per hectare in exclusively pasture-based systems with animals of low production.

Key words: Cynodon. Forage chemical composition. Grazing management. Megathyrsus. Urochloa.

\section{Resumo}

Os sistemas baseados em pastagens são predominantes entre os pequenos agricultores familiares. Muitos agricultores consideram que o valor nutricional da planta é mais relevante que a estrutura do dossel. Este estudo teve como objetivo analisar os vários fatores relacionados à estrutura da planta e a composição química que mais influenciam a produção de leite por hectare sob lotação rotativa. $O$ experimento foi realizado na Estação Experimental de Pecuária do Extremo Sul da Bahia. Três sistemas de lotação rotacionada com três espécies forrageiras [Cynodon dactylon (L.) Pers. cv. Tifton 85, Urochloa brizantha (Hochst. Ex A. Rich.) Stapf. cv. Xaraés e Megathyrsus maximus Jacq. cv. Mombaça] foram avaliados. Nove vacas mestiças Holandês $\times$ Gir foram distribuídas em um quadrado latino equilibrado $3 \times 3$. As vacas foram rotacionadas em três pastos a cada 14 dias. O período experimental consistiu de sete ciclos de avaliação de 42 dias cada. Análise de cluster, análise de componentes principais e regressão linear multivariada foram as técnicas estatísticas utilizadas para avaliar as características estruturais e morfológicas das plantas e o desempenho animal. O capim-Xaraés e o capim-Mombaça foram semelhantes para todas as características avaliadas $(P>0,05)$, enquanto o Tifton 85 foi diferente em termos de características estruturais, morfológicas e de composição química $(P<0,05)$. Na PCA, 59,1\% da variância total foi explicada pelos componentes 1 e 2 para as características estruturais e morfológicas, e a composição química da forragem. As variáveis estruturais e morfológicas das forrageiras apresentaram melhores resultados na análise de regressão linear multivariada para a produção de leite por hectare. Características estruturais e morfológicas foram mais correlacionadas com o capim-Mombaça do que para os capins Xaraés e Tifton 85. As características estruturais e morfológicas das forragens foram o principal fator determinante da produção de leite por hectare em sistemas baseados exclusivamente à pasto com animais de baixa produção.

Palavras-chave: Cynodon. Composição química da forragem. Manejo do pastejo. Megathyrsus. Urochloa. 


\section{Introduction}

Milk production has great importance for Brazilian livestock farming. National dairy farming has evolved continuously, resulting in a steady growth in milk production over recent decades (Anuário Leite, 2018). National milk production almost quadrupled from 7.1 billion liters in 1974 to more than 35.1 billion liters in 2014, making Brazil the fourthlargest producer of milk in the world (Anuário Leite, 2018). Two production systems are predominant in the national scenario: pasture and free stall barn. Pasture-based systems are prevalent among small-scale family farms (Instituto Brasileiro de Geografia e Estatísticas [IBGE], 2018). Studying pasture-based milk production is relevant not only because it is the predominant system, but it also usually has low levels of productivity (Legrand, von Keyserlingk, \& Weary, 2009).

The favorable climatic characteristics for forage production and land area contribute tothepredominance of pasture-based systems in Brazil. The total area of grassland in the country is 159 million ha (IBGE, 2018), of which cultivated pastures represent approximately $70 \%$ of the total pasture area (IBGE, 2018). Urochloa, Megathyrsus, and Cynodon are the main genus of cultivated species (S. C. Silva, Sbrissia, \& Pereira, 2015), but Urochloa spp. represents the most substantial proportion (85\%) of cultivated pastures in Brazil (Jank, Barrios, Valle, Simeão, \& Alves, 2014). Grasses of the genus Megathyrsus are alternative options to Urochloa for intensive livestock production in fertile areas due to its high production capacity (Maciel et al., 2018). Grasses of the genus Cynodon, as well as their intra- and inter-specific hybrids, are creeping grasses that spread either by stolons, rhizomes, or both (Silva et al., 2015) and are characterized by high nutritional value if adequately managed (Borges et al., 2017).

Research has sought to understand the interaction between each type of plant and the grazing animal (Provenza, Gregorini, \& Carvalho, 2015), given the large number of forage genotypes available. The development of grazing management strategies based on pasture targets, particularly canopy height, has become an essential requirement for increasing livestock production and reducing the amount of land used (Rouquette, 2015; Silva et al., 2015). Thus, management strategies defined through research would allow substantial progress on many questions, which would provide conditions for better adjustments of current grazing management practices in Brazil (Congio etal., 2018; Gregorini et al., 2011; Muñoz et al., 2016). However, the adoption of grazing management practices by farmers is minimal. This fact, coupled with low adoption of technology, has resulted in low productivity per animal and per area (Martha, Alves, \& Contini, 2012).

The canopy structure and forage nutritional value regulate forage intake in grazing ruminants (Fonseca et al., 2013). Forage intake is more affected by grazing management than nutritional value (Silveira et al., 2016). However, many farmers consider that the nutritional value of the plant is more relevant than canopy structure, leaving aside grazing management strategies (Allison, 1985; Rouquette, 2015). A typical case involves nitrogen fertilization in pasture management. Farmers are typically convinced that pastures fertilized with nitrogen will improve animal performance due to the higher nutritional value of the plant (Delevatti et al., 2019). However, 
increases in plant growth rate through fertilization will limit forage intake if grazing management practices are not adopted (Euclides et al., 2018; Geremia, Pereira, Paiva, Oliveira, \& Silva, 2014).

Understanding the main factors affecting pasture-based production systems will help develop grazing management strategies to improve the structural characteristics of the plant and maximize animal performance. Therefore, we hypothesized that canopy structural and morphological characteristics have more influence on pasture milk production than forage chemical composition characteristics. Furthermore, forage plants with an erect growth habit have greater correlation with structural and morphological characteristics than forage with stoloniferous growth. This study aimed to evaluate the effect of structural, morphological, and forage chemical composition characteristics on milk yield per hectare in tropical grass pasture with different canopy structures.

\section{Materials and Methods}

\section{Experiment study area}

This experiment was performed at the Animal Husbandry Experimental Station of the Extreme South of Bahia (ESSUL) belonging to the Cocoa Research organization (CEPLAC/ CEPEC) in the municipality of Itabela $\left(16^{\circ}\right.$ $39^{\prime} \mathrm{S}$ and $39^{\circ} 30^{\prime} \mathrm{W}, 918 \mathrm{~m}$ above sea level). According to Köppen's classification, the climate of the region is transitional between tropical rainforest climate (Af) and tropical monsoon climate $(\mathrm{Am})$, with a mean annual rainfall of $1311 \mathrm{~mm}$, and mean temperature of $25^{\circ} \mathrm{C}$ (Peel, Finlayson, \& McMahon, 2007). Meteorological data were obtained at a weather station located $1000 \mathrm{~m}$ southeast of the experimental area (Figure 1).

The soil in the area is an Acrisol (WRB/ FAO classification) or a "Latossolo Amarelo Distrocoeso" according to the Brazilian classification (Empresa Brasileira de Pesquisa Agropecuária [EMBRAPA], 2018). Soil texture is sandy at the surface, but clay content increases with depth from $160(0-5 \mathrm{~cm})$ to $250 \mathrm{~g}$ clay kg soil-1 $(20-30 \mathrm{~cm})$. Soil analyses were carried out using Embrapa standard techniques (Claessen, Barreto, Paula, \& Duarte, 1997) and revealed the following properties: $\mathrm{pH}$ $\left(\mathrm{H}_{2} \mathrm{O}\right)=5.9$; exchangeable $\mathrm{Al}, \mathrm{Ca}, \mathrm{Mg}$, and $\mathrm{K}$ of $0.0,1.9,0.44$, and $0.1 \mathrm{cmol}_{\mathrm{c}} \mathrm{dm}^{-3}$, respectively; available $\mathrm{P}($ Mehlich $\mathrm{I})=3 \mathrm{mg} \mathrm{dm}^{-3}$. 


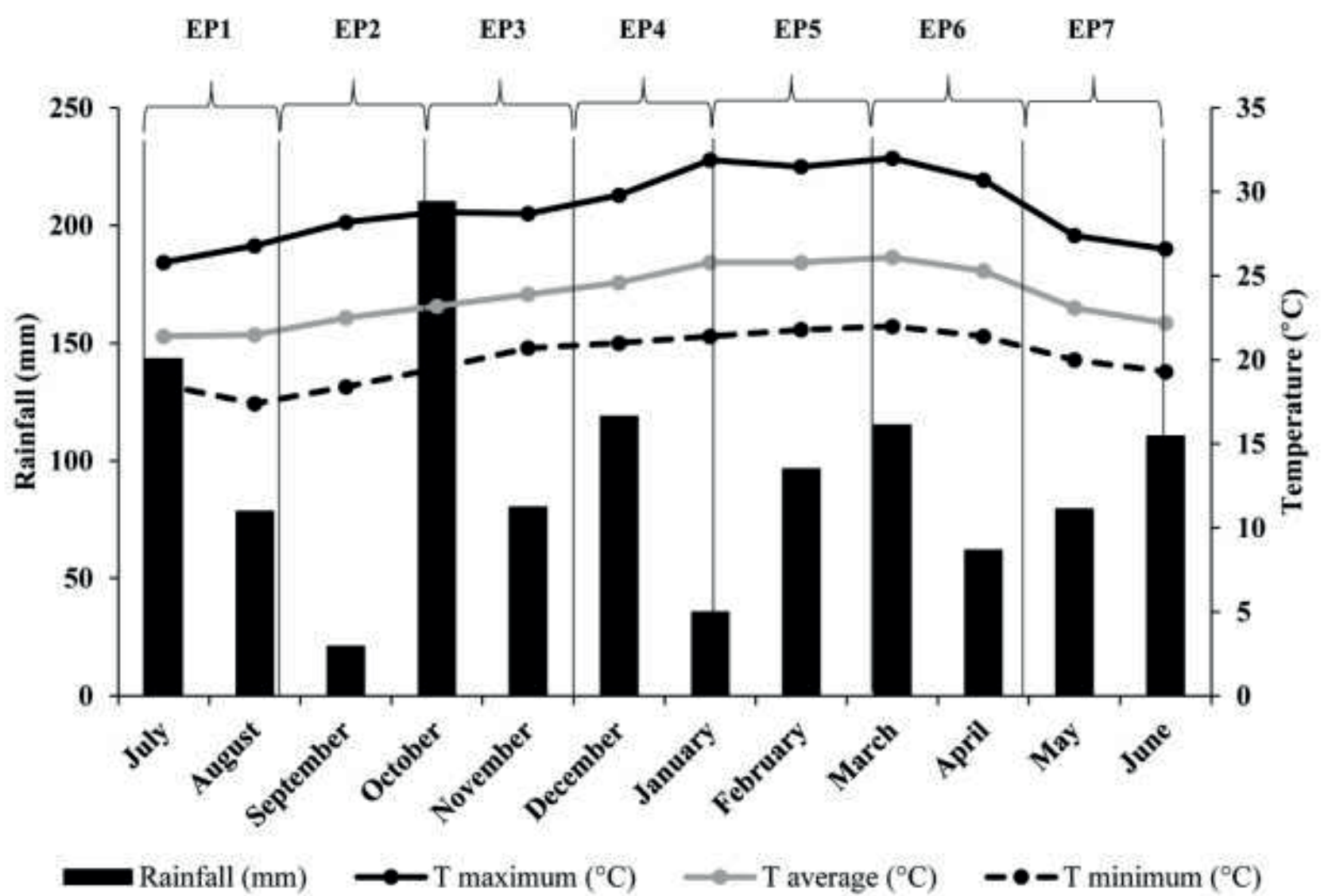

Figure 1. Mean monthly temperatures and rainfall in Itabela, South of Bahia, Brazil, during the experiment period.

\section{Production system}

Three rotational stocking systems with different forage species were evaluated in 2014 and 2015. For sowing, liming and phosphate fertilization were performed according to the soil analysis. A total of 1.5 tons $\mathrm{ha}^{-1}$ of dolomitic limestone and $450 \mathrm{~kg}$ $\mathrm{ha}^{-1}$ of single superphosphate fertilizer were applied to increase the base saturation to 70 and the phosphorus content to $25 \mathrm{mg}$ $\mathrm{dm}^{-3}$, respectively. The studied forages were Cynodon dactylon (L.) Pers. cv. Tifton 85 (Tifton 85), Urochloa brizantha (Hochst. ex A. Rich.) Stapf. cv. Xaraés (Xaraés palisadegrass), and Megathyrsus maximus Jacq. cv. Mombasa
(Mombasa guinea grass). The experimental area with Tifton 85 was divided into 18 paddocks of $667 \mathrm{~m}^{2}$, while areas with Xaraés palisadegrass and Mombasa guinea grass were divided into 28 paddocks of $429 \mathrm{~m}^{2}$ each.

In rotational stocking systems, the paddocks are submitted to rest and grazing periods. Thus, for Tifton 85, the rest and grazing periods were 34 days and two days, respectively. For Mombasa guinea grass and Xaraés palisadegrass, the rest and grazing periods were 27 days and one day, respectively. The stubble height target was set to $60 \%$ of the pre-grazing canopy height (Fonseca et al., 2012). During a grazing cycle, 
put-and-take dry cows were used to adjust the stocking rate according to the criterion of maintaining stubble height target and grazing period.

Nitrogen and potassium fertilization were performed at the end of the grazing cycle using $300 \mathrm{~kg} \mathrm{~N}$ hectare ${ }^{-1}$ year-1 $^{-1}$ in the form of urea, and $240 \mathrm{~kg} \mathrm{~K}_{2} \mathrm{O}_{\text {hectare }}{ }^{-1}$ year $^{-1}$ in the form of potassium chloride, respectively. Fertilizer application was equally divided by the number of grazing cycles. Additionally, an irrigation system was used with sprinklers spaced $15 \mathrm{~m}$ apart from each other. Irrigation management was carried out on a supplementary basis with a six-day fixed watering shift and based on rainfall events, average air temperature, and evapotranspiration from data collected at the meteorological station.

\section{Measurements}

\section{Canopy height and forage mass}

The average canopy height was measured using a sward stick (Barthram, 1985) at 50 random points per paddock before (CHpre) and after grazing (CHpost). Forage mass (pre- and post-grazing) were sampled by using six frames of $1 \times 0.5 \mathrm{~m}$ per paddock, once for each grazing cycle. After harvesting, the forage and morphological components were separated. Forage samples were separated into leaf (leaf blade), stem (stem + sheath), and senescent/dead material, and subsequently oven-dried at $55^{\circ} \mathrm{C}$ for 72 $\mathrm{h}$ to a constant weight for determinations of pre- and post-grazing forage masses, leaf and stem masses (FMpre, LFMpre, SFMpre and FMpost, LFMpost, SFMpost, respectively). The difference in height and forage mass, and leaf and stem mass obtained in the pre- and post-grazing were used to calculate the grazing severity (GS; \%); total, leaf, and stem disappearance rates in kilograms and percentage of pre-grazing mass (DF, LFMD, SFMD, \%LFMD, \%SFMD, respectively).

\section{Chemical composition of the forage mass}

Oven-dried samples of pre-grazing forage mass and leaves of each grazing cycle were ground in a Cyclotec mill (Tecator, Herndon, VA) to pass through a 1-mm screen. The dry matter (DM) of each sample was obtained by drying in an oven at $100^{\circ} \mathrm{C}$ for $18 \mathrm{~h}$ (Association of Official Analytical Chemists [AOAC], 2000). The ash content was determined by incineration in a muffle furnace at $600{ }^{\circ} \mathrm{C}$ for $3 \mathrm{~h}$ (AOAC, 2000). The crude protein (CP) content was calculated based on the $\mathrm{N}$ concentration $(\mathrm{CP}=$ total $\mathrm{N} \times 6.25)$, which was determined using the Kjeldahl procedure (AOAC, 2000). The lignin was analyzed according to method 973.18D (AOAC, 2000). The ash-free neutral detergent fiber (NDF) was determined sequentially by the autoclave method at $105^{\circ} \mathrm{C}$ for $60 \mathrm{~min}$ (Pell \& Schofield, 1993). The in vitro DM digestibility (IVDMD) was determined using the DAISYII method (Ankom Technology Corp., Fairport, NY) for 48 h (Holden, 1999). Rumen fluid was collected before feeding from two cannulated heifers fed a diet that consisted of Urochloa grass pasture fertilized with $150 \mathrm{~kg}$ of $\mathrm{N} \mathrm{ha}^{-1}$ year $^{-1}$ in the form of urea.

\section{Animal performance}

Nine crossbred Holstein x Gyr cows were allotted to a balanced $3 \times 3$ Latin square design and distributed in groups according to 
lactation period, as follows: cows with up to 75 days in milk, cows with 76-150 days milk, and cows with 151-225 days milk, being three cows of each lactation period. The cows were rotated in three pastures every 14 days. The experiment consisted of seven measurement periods in animals of 42 days each (the total period where the cows grazed all forage sources).

Milk yield (MY; kg cow ${ }^{-1}$ day $^{-1}$ ) was evaluated daily only from tester cows, which presented a MY of $8.1 \pm 0.5 \mathrm{~kg} \mathrm{cow}^{-1}$ day $^{-1}$ before the experiment. The cows were milked once per day at 07:00 h without concentrate in the diet. Milk production from the first four days was ignored because groups of cows were rotated every 14 days in the three forage sources. The cows were weighed at the end of each grazing cycle. Based on the results of animal body weight (BW) and forage mass, the pre and post forage allowance (FApre and FApost; $\mathrm{kg}$ of forage mass $\mathrm{kg} \mathrm{BW}^{-1}$ ) were calculated. At the end of each grazing cycle, the stocking rate (animal unit [AU] ha-1; AU was considered a cow weighing $500 \mathrm{~kg}$ according to Allen et al. (2011)) was calculated as the sum of BW of tester and "put-and-take" animals. The milk yield per hectare (MYH) of cows from each forage system was calculated by multiplying the daily milk yield by the average stocking rate of the system.

\section{Statistical analysis}

Three multivariate techniques were used for data analysis. Initially, clustering was performed on all studied variables using the nearest neighbor technique. The squared Euclidean distance was used to calculate the similarity matrix. Data were analyzed using the
GLM procedure of SAS (SAS Institute, Cary NC). Means for forage traits were estimated using the LSMEANS procedure and compared by Fisher's protected least significant difference test with $P \leq 0.05$. The seven experimental periods were considered replications.

Multivariate analysis was carried out using the principal component analysis (PCA) method, generating a biplot graph with the prcomp functions from the stats package ( $R$ Core Team [R], 2018), and a ggbiplot from the ggbiplot package (Viu, 2011), together with the assistance of the vegan (Oksanen et al., 2018), tidyverse (Wickham, 2017), and devtools packages (Wickham \& Chang, 2018).

The multivariate linear regression technique was used to generate conceptual models, in which the dependent variable chosen was MYH. Two simulations were performed, which generated four conceptual models. MYH was simulated with the structural and morphological characteristics + chemical composition characteristics, and vice versa. The best model was chosen based on the simplest and best represented $\mathrm{MYH}$. The change of $\mathrm{R}^{2}$ was used as the selection criterion. The comparisons between the predicted and real values were based on the significance of the regression between the two data sets (Mayer, Stuart, \& Swain, 1994), residual analysis, accuracy (Cb) (Lawrence \& Lin, 1989), the mean squared error of prediction (MSEP) (Bibby \& Toutenburg, 1977), and the partition of sources of variation of MSEP (standard error of the mean, systematic error, and random error) (Theil, 1961). These statistics were calculated using the Model Evaluation System (MES, v.3.0.1, http://nutritionmodels.tamu.edu/ mes.htm) (Tedeschi, 2006). 


\section{Results and Discussion}

In the cluster analysis, Xaraés palisadegrass and Mombasa guinea grass were similar for all evaluated characteristics (Figure 2), whereas Tifton 85 was different from them in terms of structural, morphological, and chemical composition characteristics in all periods evaluated. These results highlight the importance of pasture management (Silva et al., 2015). These characteristics are genetically determined and are often related to the growth habit and morphophysiological traits of the plant (Castro-Montoya \& Dickhoefer, 2020). Thus, while Xaraés palisadegrass, being a forage of the Urochloa genus, has its own grazing management targets, its growth habit is very similar to Mombasa guinea grass. This is likely the reason for Xaraés palisadegrass and Mombasa guinea grass being grouped together in the cluster analysis.

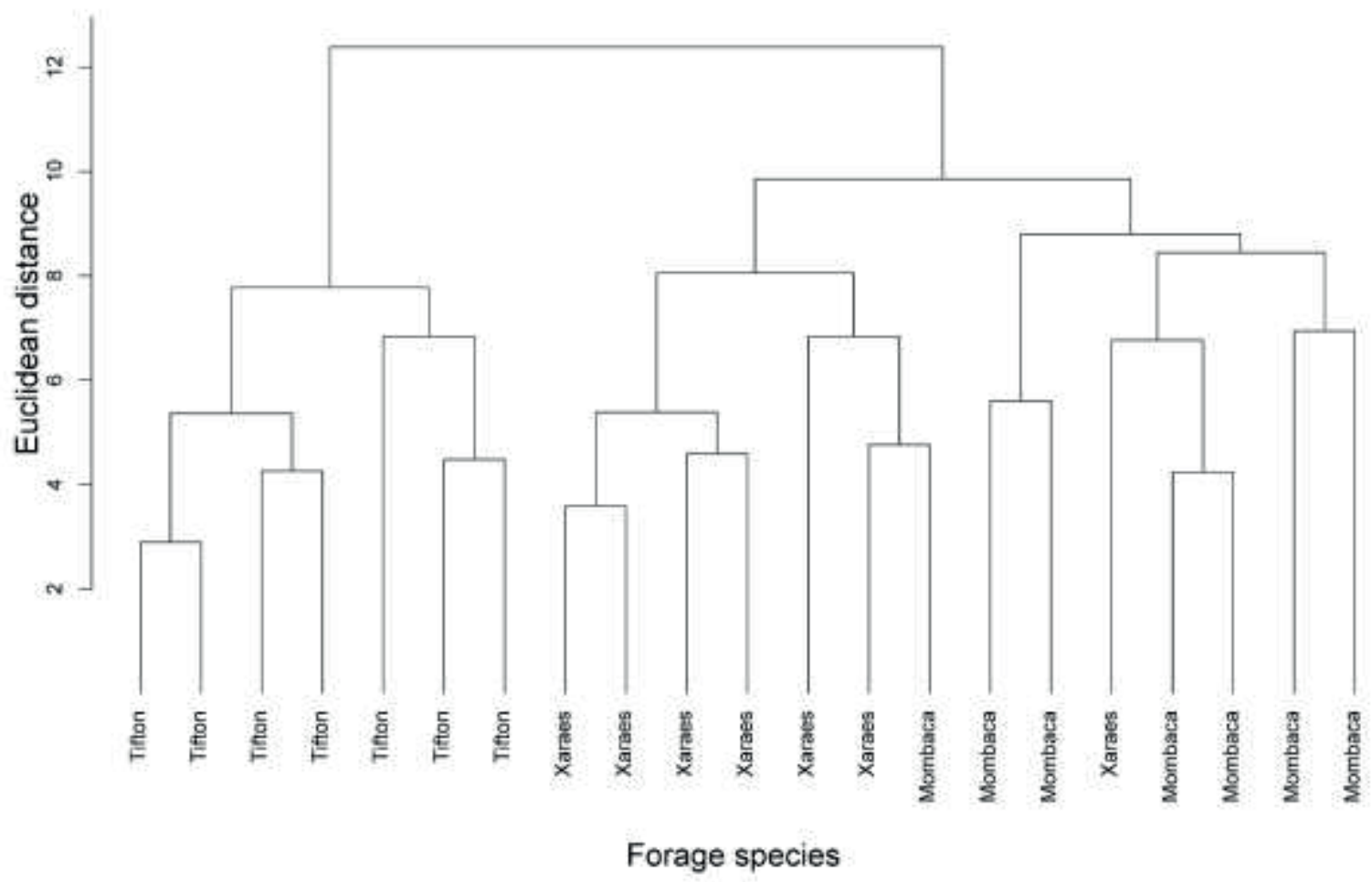

Figure 2. Cluster analysis of structural and morphological characteristics, and chemical composition of different forages.

Regarding the structural and the Xaraés and Mombasa pastures; $\mathrm{P}=0.014$ ). morphological characteristics, CHpre, CHpost, FMpre, FMpost, LFMpre, LFMpost, SFMpre, and SFMpost were lowest in Tifton 85 pastures $(P<0.001$; Table 1). The \%GS was greater in Tifton 85 pastures $(0.60$ vs. 0.46 and 0.50 for For disappearance of forage, the greater defoliation was observed in Mombasa guinea grass and Xaraés palisadegrass pastures $(P=$ 0.001). There was no effect of forage species on LFMD and \%SFMD ( $P=0.339$ and $P=0.204)$. 
The greatest values for \%LFMD and lowest for SFMD were observed in Tifton 85 pastures ( $P=0.001$ and $P=0.001$, respectively). There was a significant effect of forage species on \%LFMpre and \%LFMpost $(P=0.019$ and $P=0.021$, respectively). The \%LFMpre was greater and \%LFMpost was lower in Tifton 85 than in Mombasa guinea grass and Xaraés palisadegrass. There was a significant effect of forage species on FApre and FApost $(P<$ 0.001 and $P<0.001$, respectively), with greater values for Mombasa guinea grass and Xaraés palisadegrass.

Mombasa guinea grass and Xaraés palisadegrass had greater forage mass and canopy heights in the pre and post conditions (Table 1). This greater forage mass is often associated with an increase in stem mass (Silva,
Silva, Escobar-Guttiérrez, Lemaire, \& Louarn, 2019). Mombasa guinea grass and Xaraés palisadegrass had a greater proportion of stem in the forage mass $(8.0 \%$ and $12.0 \%$ more than Tifton 85, respectively). Forages with an erect growth habit develop structures to provide mechanical support to the aerial part of the plant (Silva et al., 2015), leading to increased plant height. Moreover, tropical grasses in monoculture managed for long rest periods are characterized by an increased proportion of stems in the upper stratum of the canopy (Silveira et al., 2016), limiting intake (Fonseca et al., 2012, 2013), which would also limit \%GS. Besides, the greater stem contribution in the upper stratum of the canopy reduces the $\mathrm{CP}$ content and increases the NDF content of the canopy to be grazed (Gomes et al., 2018).

\section{Table 1}

Structural and morphological characteristics, and chemical composition of forage and animal productivity on Xaraés palisadegrass, Mombasa guinea grass and Tifton-85 pastures

\begin{tabular}{|c|c|c|c|c|c|}
\hline \multirow{2}{*}{ Variable } & \multicolumn{3}{|c|}{ Treatments } & \multirow{2}{*}{ SEM } & \multirow{2}{*}{ P-value } \\
\hline & Xaraés & Mombasa & Tifton-85 & & \\
\hline \multicolumn{6}{|c|}{ Structural and morphological characteristics pre-grazing } \\
\hline CHpre & $55.8 b$ & $85.2 a$ & $34.2 c$ & 2.7 & 0.001 \\
\hline FMpre & $4244 a$ & $4795 a$ & $1787 b$ & 236 & 0.001 \\
\hline LFMpre & $1354 a$ & $1337 a$ & $713 b$ & 79.5 & 0.001 \\
\hline SFMpre & $2889 a$ & $3459 a$ & $1074 b$ & 233 & 0.001 \\
\hline FApre & $1.7 \mathrm{a}$ & $1.9 a$ & $0.7 b$ & 0.09 & 0.001 \\
\hline \multicolumn{6}{|c|}{ Structural and morphological characteristics post-grazing } \\
\hline CHpost & $35.2 b$ & $48.7 a$ & $22.7 c$ & 1.3 & 0.001 \\
\hline FMpost & $2273 a$ & $2370 a$ & $709 b$ & 138 & 0.001 \\
\hline LFMpost & $633 a$ & $749 a$ & $147 b$ & 56.1 & 0.001 \\
\hline SFMpost & $1640 a$ & $1622 a$ & $561 b$ & 123 & 0.001 \\
\hline FApost & $0.90 a$ & $0.94 a$ & $0.28 b$ & 0.05 & 0.001 \\
\hline
\end{tabular}

continue... 
contuation...

\begin{tabular}{|c|c|c|c|c|c|}
\hline \multicolumn{6}{|c|}{ Forage disappearance } \\
\hline$\% G S$ & $0.46 b$ & $0.50 b$ & $0.60 a$ & 0.02 & 0.008 \\
\hline DF & 1970a & $2425 a$ & $1078 b$ & 160 & 0.001 \\
\hline LFMD & 721 & 588 & 566 & 79.9 & 0.339 \\
\hline \%LFMD & $0.52 b$ & $0.44 b$ & $0.78 a$ & 0.04 & 0.001 \\
\hline SFMD & $1249 b$ & $1837 a$ & $512 c$ & 154 & 0.001 \\
\hline$\% S F M D$ & 0.43 & 0.52 & 0.47 & 0.04 & 0.204 \\
\hline \multicolumn{6}{|c|}{ Forage chemical composition and digestibility } \\
\hline Ash $_{\mathrm{FM}}$ & $8.0 \mathrm{~b}$ & $8.9 a$ & $7.7 b$ & 0.32 & 0.027 \\
\hline $\mathrm{OM}_{\mathrm{FM}}$ & $92.0 a$ & $91.1 b$ & $92.3 a$ & 0.32 & 0.027 \\
\hline $\mathrm{CP}_{\mathrm{FM}}$ & $9.6 b$ & $9.9 b$ & $12.1 a$ & 0.73 & 0.001 \\
\hline $\mathrm{NDF}_{\mathrm{FM}}$ & $74.6 a$ & $70.8 b$ & $68.5 b$ & 1.1 & 0.009 \\
\hline $\operatorname{Lig}_{F M}$ & 6.1 & 7.2 & 5.2 & 0.81 & 0.257 \\
\hline $\mathrm{IVDMD}_{\mathrm{FM}}$ & 59.7 & 58.3 & 57.8 & 1.5 & 0.532 \\
\hline $\mathrm{AshL}_{\mathrm{FM}}$ & $7.7 b$ & $9.0 a$ & $7.2 \mathrm{c}$ & 0.24 & 0.001 \\
\hline $\mathrm{OM}_{\mathrm{LFM}}$ & $92.3 c$ & $90.9 c$ & $92.8 a$ & 0.24 & 0.001 \\
\hline $\mathrm{CP}_{\mathrm{LFM}}$ & $10.8 b$ & $11.0 b$ & $15.9 a$ & 1.1 & 0.008 \\
\hline $\mathrm{NDF}_{\text {LFM }}$ & $72.3 a$ & $72.2 a$ & $64.8 \mathrm{~b}$ & 1.5 & 0.004 \\
\hline $\operatorname{Lig}_{\mathrm{LFM}}$ & 2.6 & 4.8 & 3.8 & 0.71 & 0.082 \\
\hline IVDMD $_{\text {LFM }}$ & 65.4 & 62.0 & 62.3 & 1.4 & 0.199 \\
\hline \multicolumn{6}{|c|}{ Animal productivity } \\
\hline SR & 5.2 & 4.6 & 4.5 & 0.39 & 0.217 \\
\hline MY & 6.8 & 6.8 & 6.9 & 0.32 & 0.889 \\
\hline MYH & 35.4 & 31.8 & 30.8 & 3.05 & 0.154 \\
\hline
\end{tabular}

Pre- and post-grazing characteristics: canopy height (CHpre and CHpost, $\mathrm{cm}$ ); forage mass (FMpre and FMpost, $\mathrm{kg} \mathrm{ha}^{-1}$ ); leaf forage mass (LFMpre and LFMpost, $\mathrm{kg} \mathrm{ha}^{-1}$ ); stem forage mass (SFMpre and SFMpost, $\mathrm{kg} \mathrm{ha}^{-1}$ ); forage allowance (FApre and Fa post, of the forage mass $\mathrm{kg}$ body weight ${ }^{-1}$ ). Disappeareance of forage (DF, $\mathrm{kg} \mathrm{ha}^{-1}$ ), grazing severity (GS, \%); leaf (LFMD, $\mathrm{kg} \mathrm{ha}^{-1}$ and \%) and stem (SFMD, $\mathrm{kg} \mathrm{ha}^{-1}$ and \%) disappearances rates; stocking rate (SR, AU ha-1); milk yield $\left(\mathrm{MY}, \mathrm{kg} \mathrm{cow}^{-1}\right.$ day $\left.^{-1}\right)$; milk yield per hectare $\left(\mathrm{MYH}, \mathrm{kg} \mathrm{ha}^{-1}\right.$ day $\left.^{-1}\right)$. Chemical composition of the forage mass and leaf: crude protein (CP, \%); organic matter (OM, \%); in vitro dry matter digestibility (IVDMD, \%); neutral detergent fiber (NDF, \%); lignin (LIG, \%).

a-cLeast squares means within a row with different lowercase differ by Fisher's protected least significant difference (LSD) test at $\mathrm{P} \leq 0.05$.

For the chemical composition variables (Table 1), the values of ash content were lowest, and the organic matter content was greatest in Mombasa guinea grass $(P=$ 0.001 and $P=0.001$, respectively). Forage species did not affect IVDMD and lignin of leaves and forage mass $(P=0.199, P=0.532$,
$P=0.082$, and $P=0.257$, respectively). Forage species significantly affected forage and leaf CP $(P=0.001$ and $P=0.008$, respectively $)$ and NDF contents $(P=0.009$ and $P=0.004$, respectively). Greatest values of $\mathrm{CP}$ and lowest values of NDF were observed in Tifton 85 pastures and leaves. Cynodon species and 
cultivars, such as Tifton 85 are characterized by their higher nutritional value (Table 1 ) as a consequence of the greater proportion of leaves in the forage mass (Oliveira et al., 2011). Moreover, the greater proportion of leaves is associated with apprehension, resulting in greater \%GS and \%LFMD and lower value of \%LFMpost in Tifton 85 canopy (Table 1).

There was no effect of forage species on MY, stocking rate, and $\mathrm{MYH}(P=0.889, \mathrm{P}$ $=0.217$, and $P=0.154)$. The overall means for MY, stocking rate, and MYH were $6.8 \mathrm{~kg}$ $\mathrm{cow}^{-1}$ day $^{-1}, 4.7 \mathrm{AU} \mathrm{ha}^{-1}$, and $32.2 \mathrm{~kg}$ of milk1 ha-1 $^{-1}$ day $^{-1}$, respectively. This is because grazing management is the main factor responsible for animal performance, where each forage species deserves adequate grazing management to express its potential (Rouquette, 2015; Silva et al., 2015). Evaluating two Urochloa species (pastures of Marandu and Mulato II) under the same rotational stocking target, Demski et al. (2019) reported that cows grazed on Mulato II grass had 7\% more MY (15.2 kg cow ${ }^{-1}$ day $\left.^{-1}\right)$ compared to Marandu grass (14.1 kg cow ${ }^{-1}$ day $\left.^{-1}\right)$ and attributed this to the higher leaf:stem ratio and nutritive value of the Mulato II grass. The MY obtained in the current experiment was lower than that reported in pasture systems using tropical grasses such as elephant grass (Pennisetum purpureum), ranging from 14.1 to $16.7 \mathrm{~kg} \mathrm{cow}^{-1}$ day $^{-1}$ (Voltolini et al., 2010) and from 18.5 to $15.5 \mathrm{~kg} \mathrm{cow}^{-1}$ day $^{-1}$ (Congio et al., 2018), Mombasa guinea grass, ranging from 10.8 to $14.1 \mathrm{~kg} \mathrm{cow}^{-1}$ day $^{-1}$ (Hack et al., 2007), and Marandu and Mulato II grasses, ranging from 11.9 to $17.3 \mathrm{~kg} \mathrm{cow}^{-1}$ day $^{-1}$. In all these studies, cows with greater MY potential were used. Thus, the animals received supplements to meet their nutritional requirements, receiving $1 \mathrm{~kg}$ of concentrate for each $3 \mathrm{~kg}$ of milk produced. In the current experiment, the cows were maintained on pasture without concentrate. On the other hand, the stocking rate obtained in the current study was close to that reported by Fukumoto et al. (2010), who obtained a mean stocking rate of 4.6, 4.5, and 5.0 UA ha-1 for Marandu, Tanzania (Megathyrsus maximus Jacq. cv. Tanzania-1) and African star grass (Cynodon nlemfuensis Vanderyst cv. Estrela Africana), respectively.

In order to analyze the relationship between observed variables and summarize the results of the experiment, a PCA was performed (Figure 3). The PCA analysis $(59.1 \%$ of the total variance was explained by components 1 and 2) showed clustering of a group of structural and morphological characteristics of pasture with high positive values in PC1 (44.8\%) and average positive values in PC2 (14.3\%). Therefore, these variables were closely related and included forage mass (FMpre and FMpost), canopy height (CHpre and $\mathrm{CHpost}$ ), forage allowance (FApre and FApost), GS, and stem forage mass (SFMpre and SFMpost). This occurs because grazing management is required regardless of the stocking system used. Grazing strategies should be specific to each forage species, and canopy height is usually the main management criterion used (Silva et al., 2015). This was observed where CHpre and CHpost were grouped with other structural characteristics. Furthermore, Mombasa guinea grass had a greater correlation with these structural characteristics. Forages with high growth potential and erect growth habits need more attention concerning grazing management practice (Carnevalli, Congio, Sbrissia, \& Silva, 2021; G. P. Silva et al., 2019; S. C. Silva, Uebele, Congio, Carnevalli, \& Sbrissia, 2021). 


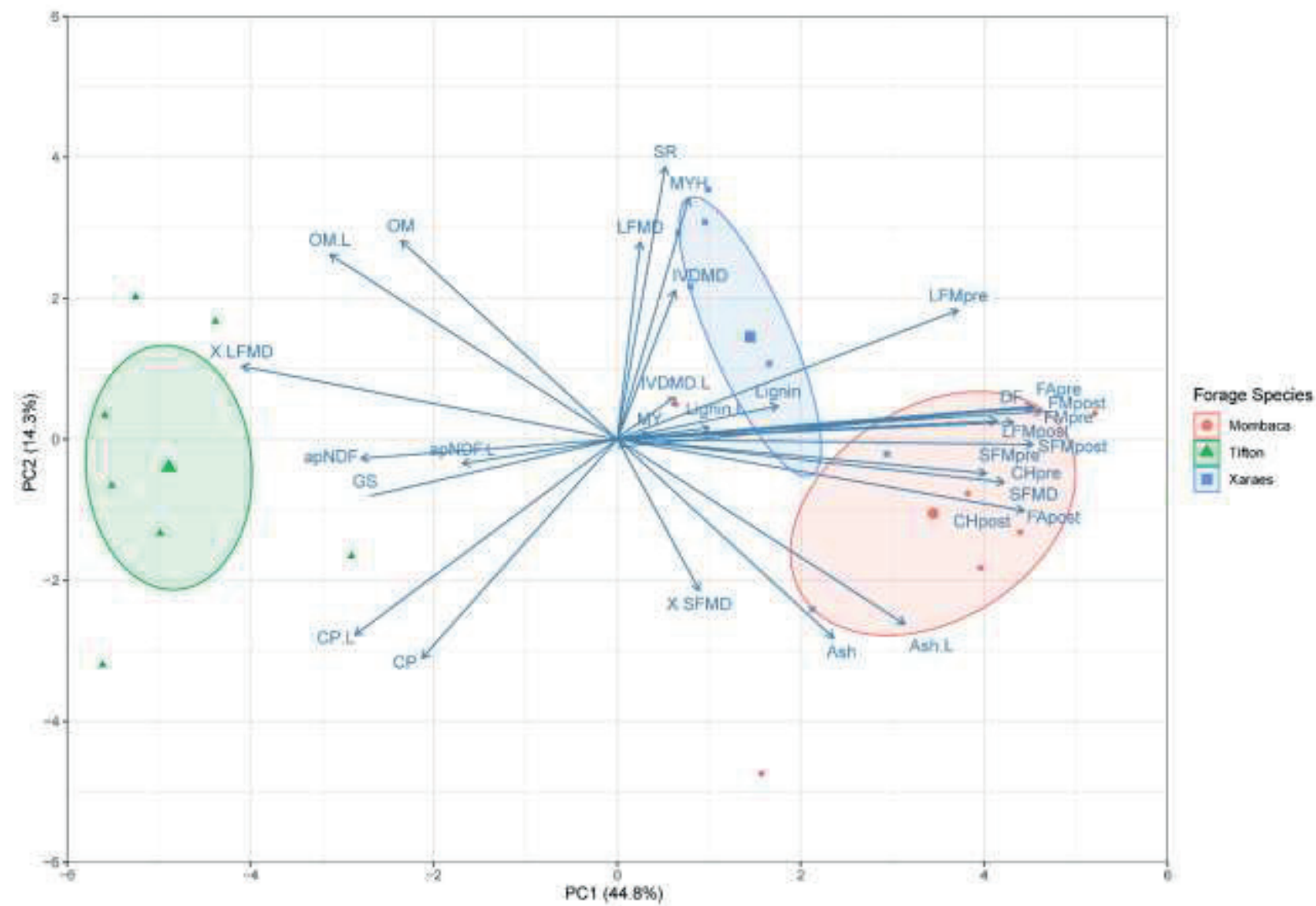

Figure 3. Principal component analysis. Pre- and post-grazing characteristics: canopy height (CHpre and CHpost, $\mathrm{cm}$ ); forage mass (FMpre and FMpost, $\mathrm{kg} \mathrm{ha}^{-1}$ ); leaf forage mass (LFMpre and LFMpost, $\mathrm{kg} \mathrm{ha}^{-1}$ ); stem forage mass (SFMpre and SFMpost, $\mathrm{kg} \mathrm{ha}^{-1}$ ); forage allowance (FApre and Fa post, $\mathrm{kg}$ of forage mass $\mathrm{kg}$ body weight $\left.{ }^{-1}\right)$. Disappeareance of forage (DF, $\left.\mathrm{kg} \mathrm{ha}^{-1}\right)$, grazing severity (GS, \%); leaf (LFMD, $\mathrm{kg} \mathrm{ha}^{-1}$ and \%) and stem (SFMD, $\mathrm{kg} \mathrm{ha}^{-1}$ and \%) disappearances rates; stocking rate $\left(\mathrm{SR}, \mathrm{AU} \mathrm{ha}^{-1}\right)$; milk yield $\left(\mathrm{MY}, \mathrm{kg} \mathrm{cow}^{-1}\right)$; milk yield per hectare $\left(\mathrm{MYH}, \mathrm{kg} \mathrm{ha}^{-1} \mathrm{day}^{-1}\right)$. Chemical composition of the forage mass and leaf: crude protein $(\mathrm{CP}, \%)$; organic matter $(\mathrm{OM}, \%)$; in vitro dry matter digestibility (IVDMD, \%); neutral detergent fiber (NDF, \%); lignin (LIG, \%).

In the PCA analysis, to interpret each principal component, it should examine the magnitude and the direction of the coefficients of the original variables. The variables, leaf organic matter, forage mass organic matter, and \%LFMpre were grouped with negative values in PC1 and average positive values in $P C 2$. In the PC2 axis, the stocking rate, LFMD, forage IVDMD, and leaf IVDMD were closely associated with positive values in PC2. Some variables associated with the forage chemical composition (forage and leaf $\mathrm{CP}$ and NDF contents) and \%GS were grouped with negative values in $\mathrm{PC} 2$ and $\mathrm{PC} 1$ (in the right quadrant and inferior part of PCA plot). Forage and leaf ash and \%SFMD were grouped with positive values in PC1 and negative values in PC2 (Figure 3). These characteristics were more correlated to Tifton 85, which as previously discussed is a species of the Cynodon genus 
shown to have a greater forage nutritive value than Mombasa guinea grass and Xaraés palisadegrass (Oliveira et al., 2011).

The multivariate analysis provided a multidisciplinary understanding of variables that affected the MYH. In the multivariate linear regression analysis, the objective was to contrast the structural, morphological, and chemical composition variables selected in the PCA with MYH. Four conceptual models were developed (Table 2). The contribution of chemical composition variables in changing the coefficient of determination $\left(\mathrm{R}^{2}\right)$ was lower compared with structural and morphological variables in both the first (model 2) and second (model 3) simulation (0.004 and 0.427 , respectively). The same was observed for the change of significance of " $F$," which was not significant $(P=0.093$ and $P=0.105$, respectively). Structural and morphological variables showed better results in both simulations $(0.988$ and 0.984 for models 1 and 4 , respectively). Thus, model 1 had the most significant $\mathrm{R}^{2}$ change, providing a reasonable estimate, with an $\mathrm{R}^{2}=0.989$ (Figure 4). The distribution of the MSEP of the model was $0.17 \%, 0.35 \%$, and $99.47 \%$, corresponding to the mean error, systematic error, and random error. Moreover, the hypothesis tested to fit the conceptual model to the first-degree equation showed no significant difference $(\mathrm{HO}: \beta 0=0, P$ $=0.772 ; \mathrm{HO}: \beta 1=1, P=0.788)$. This indicates that the observed MYH data are identical to the data estimated by the model.

\section{Table 2}

\section{Multivariate linear regression technique used to generate conceptual models in which the dependent variable used the milk yield per hectare (MYH)}

\begin{tabular}{ccccccccc}
\multicolumn{10}{c}{ Model Summary } \\
Model & R & R Square & $\begin{array}{c}\text { Adjusted } \\
\text { R Square }\end{array}$ & $\begin{array}{c}\text { Std. Error of } \\
\text { the Estimate }\end{array}$ & $\begin{array}{c}\text { R Square } \\
\text { Change }\end{array}$ & F Change & $\begin{array}{c}\text { Sig. F } \\
\text { Change }\end{array}$ & $\begin{array}{c}\text { Durbin- } \\
\text { Watson }\end{array}$ \\
\hline 1 & 0.996 & 0.992 & 0.988 & 0.844 & 0.992 & 286.932 & $0.000^{* *}$ & 2.146 \\
2 & 0.998 & 0.996 & 0.991 & 0.723 & 0.004 & 2.372 & 0.093 & \\
3 & 0.653 & 0.427 & 0.236 & 6.924 & 0.427 & 2.234 & 0.105 & 2.201 \\
4 & 0.997 & 0.995 & 0.984 & 0.986 & 0.568 & 91.488 & $0.000^{* *}$ &
\end{tabular}

* $P<0.05 ;{ }^{* *} P<0.001$.

The composition of the model are the variables: Model 1: structural and morphological characteristics only; Model 2: structural and morphological characteristics more chemical composition characteristics; Model 3: chemical composition characteristics only; Model 4: chemical composition characteristics more structural and morphological characteristics.

Grazing management modulates the canopy structure, which has an important effect on the process of forage harvesting during grazing (Benvenutti, Pavetti, Poppi, Gordon, \& Cangiano, 2016). This experiment has shown that structural and morphological characteristics have more influence on $\mathrm{MYH}$ than the chemical composition of forage mass. Canopy structure and morphological components have been identified as critical attributes for the management of grazing systems due to their strong influence on bite dimensions. The greatest intake rate in canopies with greater leaf proportion than 
stem in the grazing stratum is due to a greater bite mass associated with a faster bite rate (Carvalho et al., 2015; Guzatti et al., 2017). Furthermore, in pastures with predominant upper strata of leaves, the bite area is maximized due to the benefits of tongue movement to grasp forage (Benvenutti et al. 2016). On the other hand, in canopies with a greater presence of stem at the top strata, the bite area is limited since the shearing force of the stem is elevated (Baumont, CohenSalmon, Prache, \& Sauvant, 2004; Gregorini et al., 2011). Thus, forage intake is the main factor determining the productive performance of grazing animals (Carvalho et al., 2015).

There was no difference among forage sources for $M Y$ in the current experiment, which may suggest that the forage intake was similar among treatments. Even in pastures with different forage masses (like in the current experiment), the animals may have a similar forage intake when these pastures are managed under the same grazing management targets (Homem et al., 2021a,b). In pasture with greater forage mass, the bite mass will likely be greatest, and the grazing time will reduce. Conversely, the bite mass will likely be lower, and the grazing time will increase in pasture with lower forage mass when managed under the same grazing management targets (Homem et al., 2021a,b). Furthermore, grazing management targets allow stocking rate adjustments, which impact the enhancement of area production. Therefore, independent of the forage utilized, an adequate grazing management target should be used to achieve greater animal production.

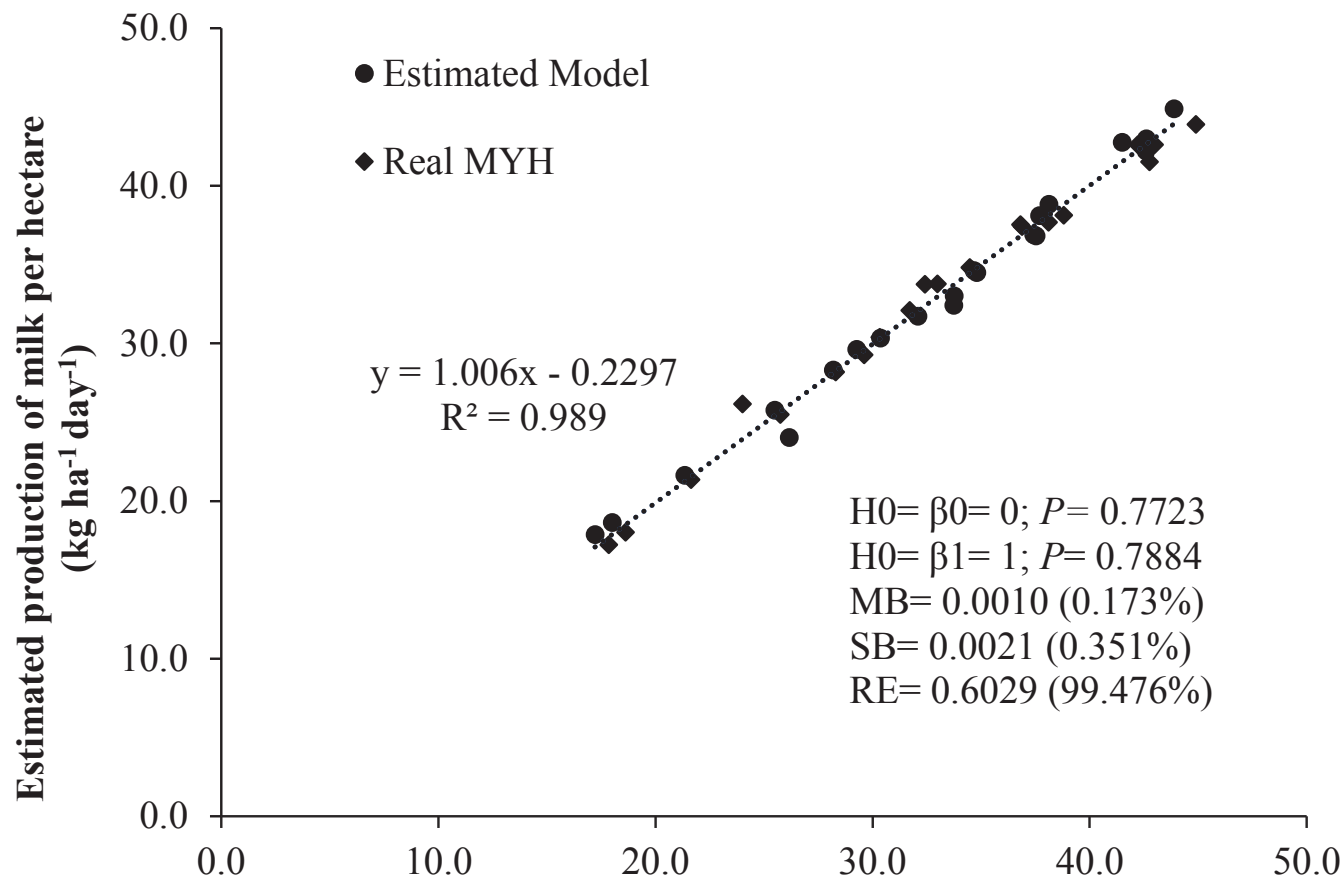

Real production of milk per hectere $\left(\mathrm{kg} \mathrm{ha}^{-1}\right.$ day $\left.^{-1}\right)$

Figure 4. Comparison between the predicted values in the conceptual model 1 with real values of milk yield per hectare. MYH: Milk yield per hectare; MB: mean bias; SB: systematic bias; RE: random errors. 


\section{Conclusion}

The forage species studied had different structural and morphological characteristics, and chemical compositions. Structural and morphological characteristics are more correlated with Mombasa guinea grass than Xaraés palisadegrass and Tifton 85. The structural and morphological characteristics of forages are the main factors determining milk yield per hectare, and are most correlated with animal-related variables in exclusively pasture-based systems with animals of low production. The forage chemical composition characteristics did not improve the milk yield per hectare estimation model in the current experiment.

\section{Acknowledgments}

This work was funded by the Minas Gerais Research Foundation (FAPEMIG), National Council for Scientific and Technological Development (CNPq), National Institute of Science and Technology in Animal Science (INCT-CA), and Coordination for the Improvement of Higher Education Personnel (CAPES).

\section{References}

Allen, V. G., Batello, C., Beretta, E. J., Hodgson, J., Kothmann, M., Li, X.,... Sanderson, M. (2011). An international terminology for grazing lands and grazing animals. Grass and Forage Science, 66(1), 2-28. doi: 10 1111/j.1365-2494.2010.00780.x

Allison, C. D. (1985). Factors affecting forage intake by range ruminants: a review. Journal of Range Management, 38(4), 305-311. doi: $10.2307 / 3899409$
Anuário Leite (2018). Indicadores, tendências e oportunidades para quem vive no setor leiteiro. São Paulo: Editora Embrapa Gado de Leite. Recuperado de https://www. embrapa.br/busca-de-publicacoes/-I publicacao/1094149/anuario-leite-20 18-indicadores-tendencias-e-oportuni dades-para-quem-vive-no-setor-leiteiro

Association of Official Analytical Chemists (2000). Official methods of analysis (17nd ed.). Arlington, VA: AOAC.

Barthram, G. T. (1985). Experimental techniques: the HFRO sward stick. In Barthram, G. T. (Ed.), The hill farming research organization (pp. 29-30). Midlothian: Biennial Report, HFRO.

Baumont, R., Cohen-Salmon, D., Prache, S., \& Sauvant, D. (2004). A mechanistic model of intake and grazing behavior in sheep integrating sward architecture and animal decisions. Animal Feed Science and Technology, 112(1-4), 5-28. doi: 10.1016/j. anifeedsci.2003.10.005

Benvenutti, M. A., Pavetti, D. R., Poppi, D. P., Gordon, I. J., \& Cangiano, C. A. (2016). Defoliation patterns and their implications for the management of vegetative tropical pastures to control intake and diet quality by cattle. Grass and Forage Science, 71(3), 424-436. doi: 10.1111/gfs.12186

Bibby, J., \& Toutenburg, H. (1977). Prediction and improved estimation in linear models. Berlin, Germany: John Wiley \& Sons.

Borges, B. M. M. N., Silveira, M. L., Cardoso, S. S., Moline, E. F. V., Coutinho, A. M., Neto, Lucas, F. T.,... Coutinho, E. L. M. (2017). Growth, herbage accumulation, and nutritive value of 'Tifton 85 ' bermudagrass as affected by nitrogen fertilization strategies. Crop 
Science, 57(6), 3333-3342. doi: 10. 2135/ cropsci2016.10.0890

Carnevalli, R. A., Congio, G. F. S., Sbrissia, A. F., \& Silva, S. C. (2021). Growth of Megathyrsus maximus cv. Mombaça as affected by grazing strategies and environmental seasonality. II. Dynamics of herbage accumulation. Crop and Pasture Science, 72(1), 66-74. doi: 10.1071/CP20199

Carvalho, P. C. F., Bremm, C., Mezzalira, J. C., Fonseca, L., Trindade, J. K. da, Bonnet, O. J. F.,... Laca, E. A. (2015). Can animal performance be predicted from short-term grazing processes? Animal Production Science, 55(3), 319-327. doi: 10.1071/AN14546

Castro-Montoya, J. M., \& Dickhoefer, U. (2020). The nutritional value of tropical legume forages fed to ruminants as affected by their growth habit and fed form: A systematic review. Animal Feed Science and Technology, 269(1), 114642. doi: 10. 1016/j.anifeedsci.2020.114641

Claessen, M. E. C., Barreto, W. O. de, Paula, J. L., \& Duarte, M. N. (1997). Manual de métodos de análise de solo. Rio de Janeiro: Centro Nacional de Pesquisa de Solos, EMBRAPA.

Congio, G. F., Batalha, C. D., Chiavegato, M. B., Berndt, A., Oliveira, P. P., Frighetto, R. T.,... Silva, S. C. (2018). Strategic grazing management towards sustainable intensification at tropical pasture-based dairy systems. Science of the Total Environment, 636(1), 872-880. doi: 10. 1016/j.scitotenv.2018.04.301

Delevatti, L. M., Cardoso, A. S., Barbero, R. P., Leite, R. G., Romanzini, E. P., Ruggieri, A. C., \& Reis, R. A. (2019). Effect of nitrogen application rate on yield, forage quality, and animal performance in a tropical pasture. Scientific Reports, 9(1), 1-9. doi: 10.1038/s41598-019-44138-X

Demski, J. P., Arcaro, I., Jr., Gimenes, F. M. A., Toledo, L. M., Miranda, M. S., Giacomini, A. A., \& Silva, G. A. (2019). Milk production and ingestive behavior of cows grazing on Marandu and Mulato II pastures under rotational stocking. Revista Brasileira de Zootecnia, 48(1), e20180231. doi: 10.15 90/rbz4820180231

Empresa Brasileira de Pesquisa Agropecuária (2018). Sistema brasileiro de classificação do solo (5a ed.). Brasília, DF: EMBRAPA Centro Nacional de Pesquisa de Solos.

Euclides, V. P. B., Carpejani, G. C., Montagner, D. B., Nascimento, D., Jr., Barbosa, R. A., \& Difante, G. S. (2018). Maintaining post-grazing sward height of Panicum maximus (cv. Mombaça) at $50 \mathrm{~cm}$ led to higher animal performance compared with post grazing height of $30 \mathrm{~cm}$. Grass and Forage Science, 73(1), 174-182. doi: $10.1111 / \mathrm{gfs} .12292$

Fonseca, L., Carvalho, P. C. F., Mezzalira, J. C., Bremm, C., Galli, J. R., \& Gregorini, P. (2013). Effect of sward surface height and level of herbage depletion on bite features of cattle grazing Sorghum bicolor swards. Journal of Animal Science, 91(9), 43574365. doi: 10.2527/jas.2012-5602

Fonseca, L., Mezzalira, J. C., Bremm, C., Arruda, R. S., Fo., Gonda, H. L., \& Carvalho, P. C. F. (2012). Management targets for maximising the short-term herbage intake rate of cattle grazing in Sorghum bicolor. Livestock Science, 145(1-3), 205-211. doi: 10.1016/j.livsci.2012.02 
Fukumoto, N. M., Damasceno, J. C., Deresz, F., Martins, C. E., Cóser, A. C., \& Santos, G. T. (2010). Produção e composição do leite, consumo de matéria seca e taxa de lotação em pastagens de gramíneas tropicais manejadas sob lotação rotacionada. Revista Brasileira de Zootecnia, 39(1), 1548-1557. doi: 10. 1590/S1516-35982010000700022

Geremia, E. V., Pereira, L. E., Paiva, A. J., Oliveira, L. P., \& Silva, S. C. (2014). Intake rate and nutritive value of elephant grass cv. Napier subjected to strategies of rotational stocking management. Tropical Grasslands-Forrajes Tropicales, 2(1), 5152. doi: 10.17138/tgft(2)51-52

Gomes, F. K., Oliveira, M. D. B. L., Homem, B. G. C., Boddey, R. M., Bernardes, T. F., Gionbelli, M. P.,... Casagrande, D. R. (2018). Effects of grazing management in brachiaria grass-forage peanut pastures on canopy structure and forage intake. Journal of Animal Science, 96(9), 3837-3849. doi: 10.1093/jas/sky236

Gregorini, P., Gunter, S. A., Bowman, M. T., Caldwell, J. D., Masino, C. A., Coblentz, W. K., \& Beck, P. A. (2011). Effect of herbage depletion on short-term foraging dynamics and diet quality of steers grazing wheat pastures. Journal of Animal Science, 89(11), 3824-3830. doi: 10.2527/ jas.2010-3725

Guzatti, G. C., Duchini, P. G., Sbrissia, A. F., Mezzalira, J. C., Almeida, J. G. R., Carvalho, P. C. F., \& Ribeiro, H. M. N., Fo. (2017). Changes in the short-term intake rate of herbage by heifers grazing annual grasses throughout the growing season. Grassland Science, 63(4), 255-264. doi: $10.1111 /$ grs. 12170
Hack, E. C., Bona, A., Fo., Moraes, A., Carvalho, P. C. F., Martinichen, D., \& Pereira, T. N. (2007). Características estruturais e produção de leite em pastos de capim-mombaça (Panicum maximum Jacq.) submetidos a diferentes alturas de pastejo. Ciência Rural, 37(1), 218-222. doi: 10.1590/S0 103-8478200 7000100035

Holden, L. A. (1999). Comparison of methods of in vitro dry matter digestibility for ten feeds. Journal of Dairy Science, 82(8), 1791-1794. doi: 10.3168/jds.S0022-0302 (99)75409-3

Homem, B. G. C., Lima, I. B. G., Spasiani, P. P., Borges, L. P., Boddey, R. M., Dubeux, J. C. B., Jr.,... Casagrande, D. R. (2021b). Palisadegrass pastures with or without nitrogen or mixed with forage peanut grazed to a similar target canopy height. 2. Effects on animal performance, forage intake and digestion, and nitrogen metabolism. Grass and Forage Science, 76(3), 1-13. doi: 10.1111/gfs.12533

Homem, B. G. C., Lima, I. B. G., Spasiani, P. P., Ferreira, I. M., Boddey, R. M., Bernardes, T. F.,... Casagrande, D. R. (2021a). Palisadegrass pastures with or without nitrogen or mixed with forage peanut grazed to a similar target canopy height. 1. Effects on herbage mass, canopy structure and forage nutritive value. Grass and Forage Science, 76(3), 1-14. doi: 10. $1111 /$ gfs. 12532

Instituto Brasileiro de Geografia e Estatísticas (2018). Censo agropecuário. Recuperado de https://biblioteca.ibge. gov.br/visualizacao/periodicos/3093/ agro 2017 resultados preliminares.pdf

Jank, L., Barrios, S. C., Valle, C. B. do, Simeão, R. M., \& Alves, G. F. (2014). The value 
of improved pastures to Brazilian beef production. Crop and Pasture Science, 65(11), 1132-1137. doi: 10.1071/CP13319

Lawrence, I., \& Lin, K. (1989). A concordance correlation coefficient to evaluate reproducibility. Biometrics, 45(1), 255268. doi: $10.2307 / 2532051$

Legrand, A. L., von Keyserlingk, M. A. G., \& Weary, D. M. (2009). Preference and usage of pasture versus free-stall housing by lactating dairy cattle. Journal of Dairy Science, 92(8), 3651-3658. doi: 10.3168/ jds.2008-1733

Maciel, G. A., Braga, G. J., Guimarães, R., Jr., Ramos, A. K. B., Carvalho, M. A., Fernandes, F. D.,... Jank, L. (2018). Seasonal liveweight gain of beef cattle on guineagrass pastures in the Brazilian cerrados. Agronomy Journal, 110(2), 480487. doi: 10.2134/agronj2017.05.0262

Martha, G. B., Jr., Alves, E., \& Contini, E. (2012). Land-saving approaches and beef production growth in Brazil. Agricultural Systems, 110(1), 173-177. doi: 10.1016/j. agsy.2012.03.001

Mayer, D. G., Stuart, M. A., \& Swain, A. J. (1994). Regression of real-world data on model output: an appropriate overall test of validity. Agricultural Systems, 45(1), 93-104. doi: 10.1016/S0308-521X (94)90282-8

Muñoz, C., Letelier, P. A., Ungerfeld, E. M., Morales, J. M., Hube, S., \& Pérez-Prieto, L. A. (2016). Effects of pregrazing herbage mass in late spring on enteric methane emissions, dry matter intake, and milk production of dairy cows. Journal of Dairy science, 99(10), 7945-7955. doi: 10.3168/ jds.2016-10919
Oksanen, J., Blanchet, F. G., Friendly, M., Kindt, R., Legendre, P., Mcglinn, D.,... Wagner, H. (2018). Vegan: community ecology packager package. Version 2.52. Retrieved from https://CRAN.R-project. org/package=vegan

Oliveira, M. A., Pereira, O. G., Ribeiro, K. G., Santos, M. E. R., Chizzotti, F. H. M., \& Cecon, P. R. (2011). Produção e valor nutritivo do capim-coastcross sob doses de nitrogênio e idades de rebrotação. Arquivo Brasileiro de Medicina Veterinária e Zootecnia, 63(3), 694-703. doi: 10.1590/ S0102-09352011000300022

Peel, M. C., Finlayson, B. L., \& McMahon, T. A. (2007). Updated world map of the KöppenGeiger climate classification. Hydrology and Earth System Sciences, 11(5), 16331644. doi: 10.5194/hess-11-1633-2007

Pell, A. N., \& Schofield, P. (1993). Computerized monitoring of gas production to measure forage digestion in vitro. Journal of Dairy Science, 76(4), 1063-1073. doi: 10.3168/ jds.S0022-0302(93)77435-4

Provenza, F. D., Gregorini, P., \& Carvalho, P. C. F. (2015). Synthesis: foraging decisions link plants, herbivores and human beings. Animal Production Science, 55(3), 411425. doi: 10.1071/AN14679

R Core Team (2018). R: a language and environment for statistical computing. Vienna: $\mathrm{R}$ Foundation for Statistical Computing. Retrieved from https:// www.R-project.org/

Rouquette, F. M., Jr. (2015). Grazing systems research and impact of stocking strategies on pasture-animal production efficiencies. Crop Science, 55(6), 25132530. doi: 10.2135/cropsci2015.01.0062 
Silva, G. P., Silva, S. C., Escobar-Guttiérrez, A., Lemaire, G., \& Louarn, G. (2019). Stem elongation in Pennisetum purpureum results from a fixed pattern of vegetative development potentially enhanced by the initiation of flowering. Grass and Forage Science, 74(4), 708-719. doi: 10.1111/ gfs. 12449

Silva, S. C., Sbrissia, A. F., \& Pereira, L. E. T. (2015). Ecophysiology of C4 forage grasses understanding plant growth for optimising their use and management. Agriculture, 5(3), 598-625. doi: 10.3390/ agriculture 5030598

Silva, S. C., Uebele, M. C., Congio, G. F. S., Carnevalli, R. A., \& Sbrissia, A. F. (2021). Growth of Megathyrsus maximus cv. Mombaça as affected by grazing strategies and environmental seasonality. I. Tillering dynamics and population stability. Crop and Pasture Science, 72(1), 55-65. doi: 10.1071/CP20198

Silveira, M. C. T., Nascimento, D., Jr., Rodrigues, C. S., Pena, K. S., Souza, S. J., Jr., Barbero, L. M.,... Silva, S. C. da. (2016). Forage sward structure of Mulato grass ('Brachiaria hybrid' ssp.) subjected to rotational stocking strategies. Australian Journal of Crop Science, 10(6), 864. doi: 10.21475/ ajcs.2016.10.06.p7568
Tedeschi, L. O. (2006). Assessment of the adequacy of mathematical models. Agricultural Systems, 89(2-3), 225-247. doi: 10.1016/j.agsy.2005.11.004

Theil, H. (1961). Economic forecasts and policy. Amsterdam: North-Holland Publishing Company.

Viu, V. (2011). Ggbiplot: a ggplot2 based biplot. $\mathrm{R}$ Package version 0.55. Retrieved from http://www.vince. vu/software/

Voltolini, T. V., Santos, F. A. P., Martinez, J. C., Imaizumi, H., Clarindo, R. L., \& Penati, M. A. (2010). Produção e composição do leite de vacas mantidas em pastagens de capim-elefante submetidas a duas frequências de pastejo. Revista Brasileira de Zootecnia, 39(1), 121-127. doi: 10. 1590/S1516-35982010000100016

Wickham, H. (2017). Tidyverse: easily install and load the' tidyverse'. R Package Version 1.2.1. Retrieved from https://CRAN.Rproject.org/package=tidyverse

Wickham, H., \& Chang, W. (2018). Devtools: tools to make developing $R$ packages easier. R Package Version 1.12.0. Retrieved from https://CRAN.R-project. org/package $=$ devtools 
